九州大学学術情報リポジトリ

Kyushu University Institutional Repository

\title{
Safety Working Environment at Highway: Safety Warning Detector (SWAD) System
}

Hassan, Suhaimi

Faculty of Mechanical Engineering and Manufacturing, Universiti Tun Hussein Onn Malaysia

Norbazlan Mohd Yusof

Center of Excellence, Projek Lebuhraya Usahasama Berhad, Menara Korporat

Mohamad Shah Ikhsan

Center of Excellence, Projek Lebuhraya Usahasama Berhad, Menara Korporat

Mohamad Zhairul Iqumal Jumari

Faculty of Mechanical Engineering and Manufacturing, Universiti Tun Hussein Onn Malaysia

他

https://doi.org/10.5109/4491637

出版情報：Evergreen. 8 (3)，pp.517-523，2021-09. 九州大学グリーンテクノロジー研究教育センター バージョン：

権利関係 : 


\title{
Safety Working Environment at Highway: Safety Warning Detector (SWAD) System
}

\author{
Suhaimi Hassan ${ }^{1, *}$, Norbazlan Mohd Yusof ${ }^{2}$, Mohamad Shah Ikhsan², \\ Mohamad Zhairul Iqumal Jumari ${ }^{1}$, Mohamad Amirul Mat Nadir ${ }^{1}$,
} Mohd Hassan Helmi Ibrahim¹, Muhammad Azimuddin Mohd Nor Azman ${ }^{1}$, Muhammad Azim Farhi Mohd Sarif ${ }^{1}$, Muhammad Amir Raauf Abdul Rashid ${ }^{1}$, Mohd Sallehuddin Yusof ${ }^{1}$, Maznan Ismon ${ }^{1}$, Hanis Zakaria ${ }^{1}$, Mohd Azham Azmi ${ }^{1}$, Omar Mohd Faizan Marwah ${ }^{1}$

${ }^{1}$ Faculty of Mechanical Engineering and Manufacturing, Universiti Tun Hussein Onn Malaysia, 86400 Parit Raja, Batu Pahat, Johor, Malaysia

${ }^{2}$ Center of Excellence, Projek Lebuhraya Usahasama Berhad, Menara Korporat, Persada PLUS, Persimpangan Bertingkat Subang, KM15, Lebuhraya Baru Lembah Klang 47301 Petaling Jaya, Selangor, Malaysia

*Author to whom correspondence should be addressed:

E-mail: suhaimihas@uthm.edu.my

(Received December 28, 2020; Revised June 13, 2021; accepted July 25, 2021).

\begin{abstract}
The research study was carried out for the safety of highway maintenance workers in order to avoid incidents or hazards in the direct emergency lane on the highway through the implementation of a danger sensor device which known as Signal Warning Detector (SWAD). The distance sensor detected the object at a certain distance and sent the signal to the output via the siren device and emergency light. The device sensor was mounted on the highway worker vehicle. It also sent signal to the receiver to alert employee by giving early signal of danger detected. The receiver alerted employee by vibrating the vibrator motor that was attached at highway worker's arm. The main objective of the SWAD was to increase the safety procedure and precaution for maintenance highway workers that currently doing their job at the emergency lane of the highway. The Signal Warning Detector (SWAD) had successfully implemented by detecting the vehicle or danger from behind in 70 meter maximum distance at straight emergency lane. The SWAD was effective to be used on highway worker vehicles for additional safety by giving early danger signal.
\end{abstract}

Keywords: safety, automation system, sensor detector

\section{Introduction}

Nowadays, the safety system was one of the most important requirements to make sure employees were always safe and were not exposed to any danger ${ }^{1}$. Aspects of the security system were not confined to industries such as factories, ports, warehouses, tank storage, oil palm²) and others. However, it should be emphasized on the roadside especially the highways. In this case, the safety of the workers doing the maintenance work on the highway was much less concerned. If an accident involving an employee, it may result in serious injury or death to the employee. Highway construction and maintenance crews were often forced to work adjacent to high volumes of traffic and in many cases fast-flowing traffic. The large number of work zone accidents proved that exposure was risk and clear ${ }^{3)}$.

A highway maintenance worker was a person who ensures that the highways and roads stay in, clean and useable. There were a number of specialists in highway support, including regular operation, repaired tasks and repairing parking defects. This activity requested physical quality and the majority of working time was spent outside. In addition, road maintenance workers faced dangerous situations, including working over long distances with high-speed vehicles work in unpredictable weather conditions, and regular used of various machines ${ }^{4}$ and instruments and heavy equipment ${ }^{5}$.

A distance radar sensor as mechanical automation detection system was able to identify hazards for safety purpose ${ }^{6)}$ which coming in the opposite direction through a programmed sensor within a specified radius. The device was supported by an alarm system as well as a vibrator attached to the employee.

To ensure the system run efficiently, a reliability test would be performed to determine the level of 
effectiveness of the transmitter and receiver as well as the impact test. Reliability was the degree of consistency of a measure, the test was reliable when it gave the same repeated result under the same conditions ${ }^{7}$.

Consistency means that the measurements were replicated when different individuals measured, on different occasions, with supposedly alternative instruments that measure the same thing under different conditions $^{8)}$.

There were various types of road safety measures that had been taken by the authorities to reduce the rate of road accidents. However, the accident rate was still high as a result of the tools being made less effective. It was caused by a variety of unwanted factors. Some of which result from poor road conditions, lack of warning signs and poor road conditions. Traffic accidents happened to road users as well as road workers. In the work zone crash, a number of accident scenarios could be possible, as various contributing factors could influence probabilities and consequences $^{9)}$. Road users and highway workers had encountered accidents due to maintenance work resulting in wounds and deaths due to the less active signs since the details of road signs were supposed to be essential to understand driver's reactions ${ }^{10)}$.

The sensor technology was very useful in Industrial Revolution (IR) 4.0 in developing automation system with safety as important factor either for small or big engineering industry ${ }^{11)}$ liked micro printing technology ${ }^{12}$. The sensor application was not limited to electronic board system for programming only. But, the sensor could be apply in material composite fabrication ${ }^{13)}$, injection moulding $^{14)}$, oil palm industry, burner system ${ }^{15)}$ and automotive industry ${ }^{16)}$.

Road safety was a collective responsibility requiring participation by government, civil society and private and public enterprises also the well-planned plan and strategy were important. With infrastructure upgraded and the construction of new roads, fast growth in vehicles increased the risk of road accidents ${ }^{17}$.

The cones and safety lamps were the most widely used markers, but they were very inaccurate. Previous researcher had studied that the speed display was generally more efficient than the rumble strips in the warning area to minimize vehicle speeds ${ }^{18)}$.

The boundary of the work zone should be worried by the additional workplaces as a new safety system that decreases the danger to workers with vehicles contained and coordinated from workplaces. Research in sign substance and sign structure had been adequately applied to work zone settings. The data substance had been appeared to affect driver speed decrease at work zones. Drivers were found to rely on text messages but graphic messages were becoming increasingly viable in terms of response time and accuracy ${ }^{19)}$.

Currently numerous road safety technologies could be used to road vehicles. Modern technology could save damage to property and prevent deaths with effective security systems. Electronics played an important role in developing optimized solutions for vehicle driving, improving its safety features and reducing the environmental burden ${ }^{20}$.

Previous researcher used single black-box camera method for detecting and estimating the distance of a vehicle driving in front as shown in Fig. 1. The proposed method decomposed the input image into multipleresolution images for real-time processing and then extracted the aggregated channel features (ACFs). A method of detecting an object and a method of estimating a vehicle's distance from a bird's eye view through inverse perspective mapping (IPM) were applied. By applying IPM and transforming a 2D input image into 3D by generating an image projected in three dimensions, the distance between the detected vehicle and the autonomous vehicle was detected ${ }^{21)}$.

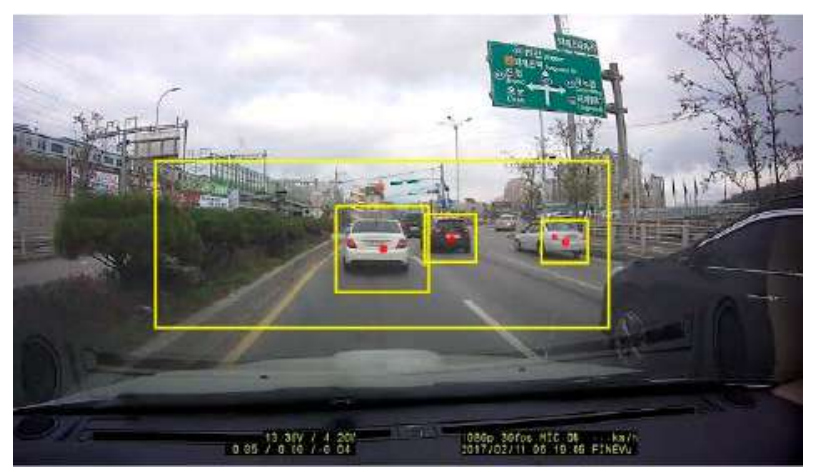

Fig. 1: The vehicle detection with the center point of the black-box camera.

Usually the safety procedure was conducted by displaying a safety sign board and blocking with safety cones while conducting the maintenance at the highway emergency lanes. However, the procedure only alert the highway users and not to the maintenance worker themselves for any danger. Therefore, those maintenance highway workers were actually needed a Signal Warning Detector (SWAD) system which could gave them the early emergency signal either by sound, vibrator or light.

\section{Methodology}

In order to complete the methodology process, a few procedures needed to choose as the best selection. Methodology data collection could be described as the process of gathering and measuring information on interest variables in a systematic manner that allowed one to respond to questions, to identify research questions, to test hypotheses and to assess results ${ }^{22)}$.

The data collection methods may vary depending on the discipline, the type of information and the intent of users. Thus, the method to collect the data was basically related to how the specific procedure to obtain the data ${ }^{23)}$.

The real situation of experimental process had been applied to find the best setting for Signal Warning Detector (SWAD) that was installed at the highway 
maintenance vehicle as shown in Fig. 2. There were some experimental had been conducted with several parameters ${ }^{24)}$ had been selected in finding the maximum danger detector distance from the vehicle.

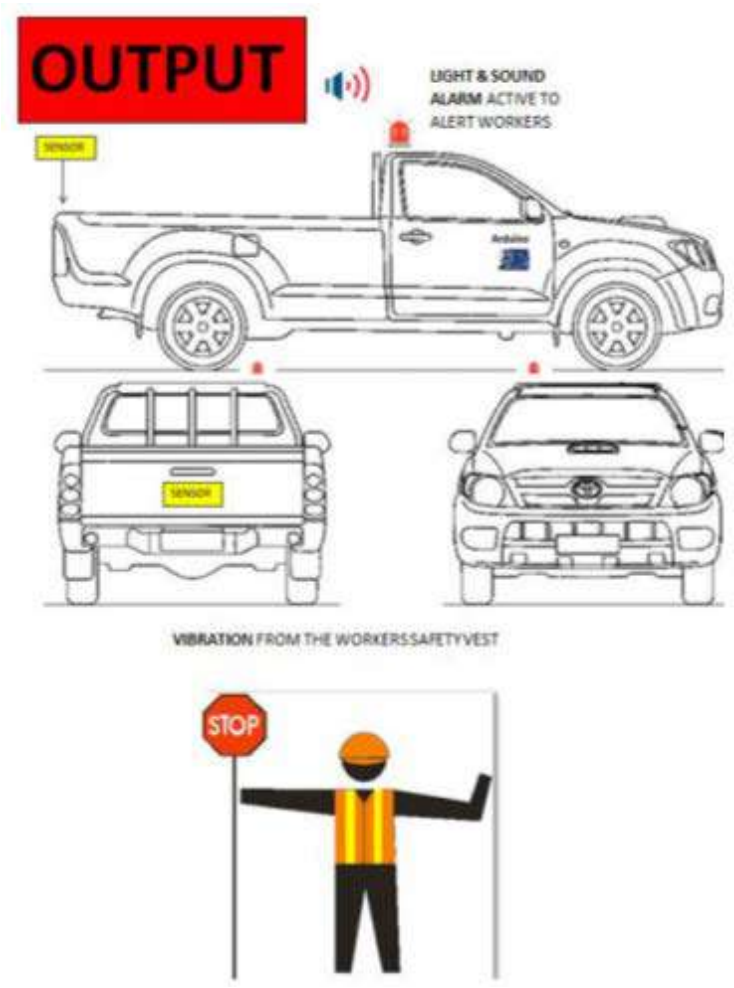

Fig. 2: The Signal Warning Detector (SWAD) that alert highway maintenance worker.

The maintenance worker vehicle was parked at emergency to gather information about its environment within 100 meter distance through the SWAD that located at the back of the vehicle. Then, it proceeded the next action to alert the maintenance worker about incoming danger.

Signal Warning Detector system was a classical optimization approach by using distance radar sensor liked showing in Fig. 3. SWAD was developed with integration of Arduino controller with distance radar sensor known as uRad sensor that had capability to detect speed and distance measurement ${ }^{25}$ ), as real safety system for highway maintenance worker.

The completed assemble of SWAD system was shown in Fig. 3. Transmitter which contained of Arduino controller and uRad sensor was installed at roof top of maintenance highway vehicle together with siren and rotation lamp as the outputs. While the receiver was installed at worker's arm.

In experimental method, the distance radar sensor and the program code administrated by Arduino as the microcontroller to detect any emergency during working or maintenance at highway straight emergency lane. Both transmitter and receiver were connected by wireless antenna.

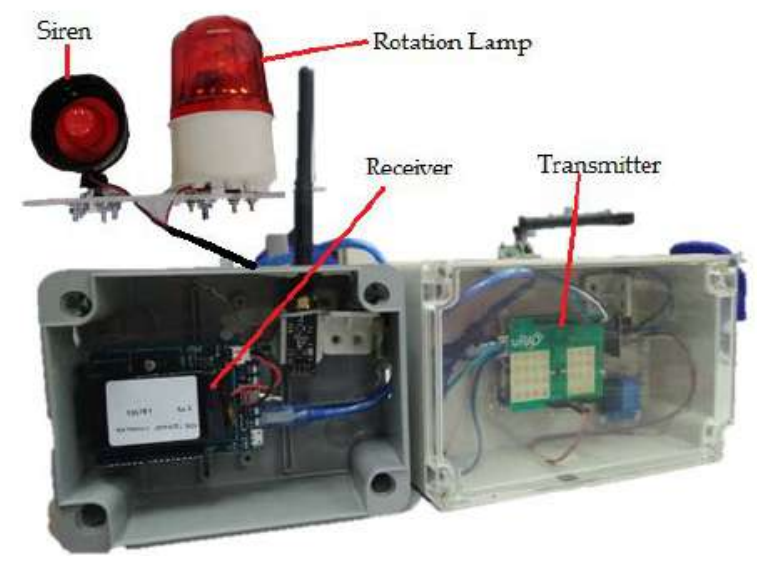

Fig. 3: The full assemble of Signal Warning Detector (SWAD) system

The factor that caused of the safety issue happening had been studied and analyzed on how this factor could affect and relate with the outcome of the problem. The necessary information to construct the automation safety system generally accumulated by the simulation and experimental works.

In experimental process, the distance in range 0 to 100 meter was measured and cones had been placed for each 10 meter liked showing in Fig. 4. SWAD system was installed at vehicle in obtaining the best distance for emergency detector which was the maximum detector. The SWAD was sent the output signal through siren, vibration and rotation light. The vehicle also was tested in the different velocity range.

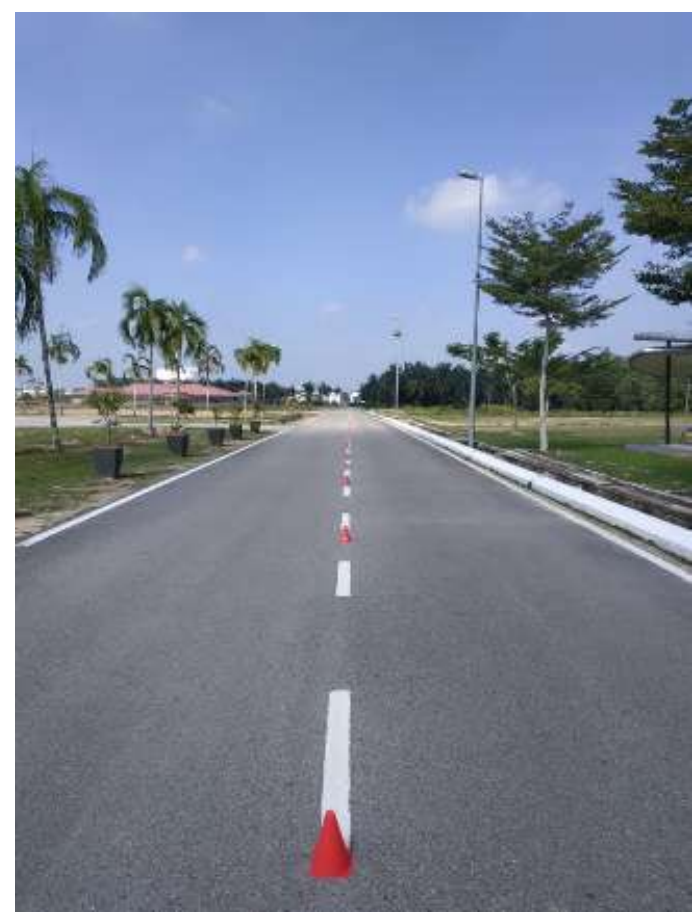

Fig. 4: The cones were placed in range 0 to 100 meter. 
The research method liked showing in Fig. 5 was conducted to achieve the objective by setting up any potential danger coming within 100 meter from the highway maintenance vehicle that was labeled as threat to the system, thus active the safety precaution process. By applying the SWAD system, it intended to help highway maintenance worker to feel safer while working, reduced unnecessary congestion or accident and improved the safety confidence of the company towards their employees. Another advantage regarding SWAD system were reduced maintenance working time and save energy used in helping the highway user for any emergency.

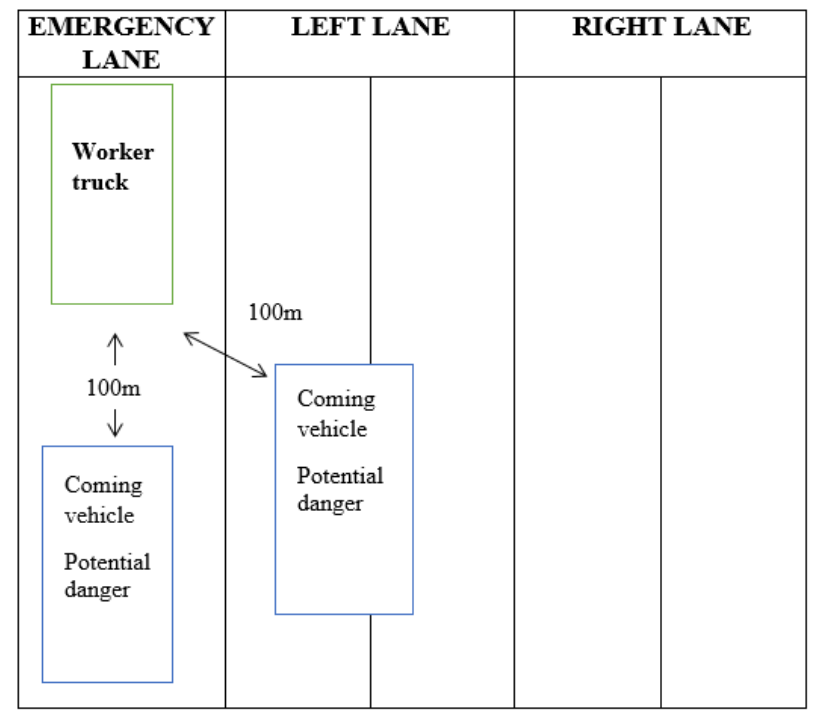

Fig. 5: The new safety precaution procedure using SWAD.

\section{Results and discussions}

The result had been obtained based on the Signal Warning Detector (SWAD) device that developed as one of the safety device made for highway maintenance worker. The development of the device was taken several period of time due to safety features and some electronic system supported by $\mathrm{C}$ language. As the device was new creation, there was no specific setting especially with their parameters setting. Due to this lack of information and data approval, some experiment had been conducted to obtain the best results for analysing.

The distance radar sensor used in this SWAD system called uRad sensor. The concept of distance sensor detected based on distribution of radar detection. The data had been obtained in this experimental testing was to find the best output or maximum distance detected purposely at highway maintenance worker vehicle as safety device for their worker. In this study, the parameter setting was studied to find the best result for each parameter due to different type of variable in this experimental. The parameter that had been set to focus were the radar distance sensor, speed range of car or any other present object from behind and the output reliability such as siren, rotation lamp and vibrator.

The first experiment was conducted in detecting the vehicle in range 0 to 100 meter distance from behind at emergency lane. Table 1 showed the presence of the movement car at different distance. The results were collected from actual field experiment test at emergency lane. From the result, this SWAD was not detected any vehicle started from 75 to 100 meter due to the radar distance sensor capability.

Table 1. The result of presence vehicle detected at emergency lane.

\begin{tabular}{|l|l|l|}
\hline $\begin{array}{l}\text { Number of } \\
\text { testing }\end{array}$ & Distance (Meter) & $\begin{array}{l}\text { Presence } \\
\text { vehicle }\end{array}$ \\
\hline 1 & $5-10$ & No \\
\hline 2 & $15-20$ & No \\
\hline 3 & $25-30$ & No \\
\hline 4 & $35-40$ & Yes \\
\hline 5 & $45-50$ & Yes \\
\hline 6 & $55-60$ & Yes \\
\hline 7 & $65-70$ & Yes \\
\hline 8 & $75-80$ & No \\
\hline 9 & $85-90$ & No \\
\hline 10 & $95-100$ & No \\
\hline
\end{tabular}

The second experiment was conducted in detecting the vehicle in range 0 to 100 meter distance at normal or slow lane. Table 2 showed the presence of the movement car at different distance. The results were collected from actual field experiment test at normal lane. From the result, this SWAD was detected vehicle at 25 to 30 meter and 45 to 60 meter distance due to the radar distance sensor setting and positioning. The data showed the gap of the study in improving the SWAD system to be more accurate in detecting the danger or emergency situation during maintenance work for highway workers.

Table 2. The result of presence vehicle detected at normal or slow lane.

\begin{tabular}{|l|l|l|}
\hline $\begin{array}{l}\text { Number of } \\
\text { testing }\end{array}$ & Distance (Meter) & $\begin{array}{l}\text { Presence } \\
\text { vehicle }\end{array}$ \\
\hline 1 & $5-10$ & No \\
\hline 2 & $15-20$ & No \\
\hline 3 & $25-30$ & Yes \\
\hline 4 & $35-40$ & No \\
\hline 5 & $45-50$ & Yes \\
\hline 6 & $55-60$ & Yes \\
\hline 7 & $65-70$ & No \\
\hline 8 & $75-80$ & No \\
\hline 9 & $85-90$ & No \\
\hline 10 & $95-100$ & No \\
\hline
\end{tabular}

The third experiment was conducted in detecting the 
vehicle at different speed in range 0 to 100 meter distance from behind at normal or slow lane. The speed range or velocity of vehicle that came from behind and object distance detected at normal lane was shown in Table 3. The trend of this graph was fluctuated where the result from experimental showed the average speed of car from 0 to $70 \mathrm{~km} / \mathrm{h}$. At velocity $10 \mathrm{~km} / \mathrm{h}, 20 \mathrm{~km} / \mathrm{h}, 40 \mathrm{~km} / \mathrm{h}$ and $70 \mathrm{~km} / \mathrm{h}$, the vehicle was not detected since the experiment was at normal lane. The result was not stable enough for different speed at normal lane due to system configuration. The data showed another gap of the study in improving the SWAD system to be more stable so that it was not detected the vehicle at normal lane and did not disturbed highway workers during maintenance works at highway emergency lane.

Table 3. The speed range of the car tested at straight emergency lane.

\begin{tabular}{|l|c|c|}
\hline $\begin{array}{l}\text { Number of } \\
\text { testing }\end{array}$ & Speed Range (km/h) & $\begin{array}{l}\text { Distance } \\
\text { Detected (m) }\end{array}$ \\
\hline 1 & 10 & - \\
\hline 2 & 20 & - \\
\hline 3 & 30 & 35 \\
\hline 4 & 40 & - \\
\hline 5 & 50 & 35 \\
\hline 6 & 60 & 30 \\
\hline 7 & 70 & - \\
\hline
\end{tabular}

The fourth experiment was conducted in detecting the vehicle at different speed in range 0 to 100 meter distance from behind at emergency lane. Table 4 showed the speed range and distance detected at emergency lane. The result trend was stable where the result from experimental showed the average speed of tested vehicle from 0 to $70 \mathrm{~km} / \mathrm{h}$. At speed $10 \mathrm{~km} / \mathrm{h}, 20 \mathrm{~km} / \mathrm{h}$ and $30 \mathrm{~km} / \mathrm{h}$, the vehicle was not detected since the SWAD programming was set to detect at minimum speed $31 \mathrm{~km} / \mathrm{h}$. The result showed different data of distance detected at certain speed set up. The highest speed which was $70 \mathrm{~km} / \mathrm{h}$ could detect the moving vehicle at 65 meter. The maximum distance detection was at 70 meter at speed $50 \mathrm{~km} / \mathrm{h}$.

Table 4. The speed range of the car tested at straight emergency lane.

\begin{tabular}{|l|c|c|}
\hline $\begin{array}{l}\text { Number of } \\
\text { testing }\end{array}$ & Speed Range (km/h) & $\begin{array}{l}\text { Distance } \\
\text { Detected (m) }\end{array}$ \\
\hline 1 & 10 & - \\
\hline 2 & 20 & - \\
\hline 3 & 30 & - \\
\hline 4 & 40 & 55 \\
\hline 5 & 50 & 70 \\
\hline 6 & 60 & 65 \\
\hline 7 & 70 & 65 \\
\hline
\end{tabular}

The graph in Fig. 6 showed the speed range in unit km/h versus distance detected at emergency lane. This lane was focused as most of highway maintenance workers worked duty at the side of the road. The result that obtained for emergency lane was conducted in detecting the vehicle at different speed in range 0 to 100 meter distance. The average speed was about $0 \mathrm{~km} / \mathrm{h}$ to $70 \mathrm{~km} / \mathrm{h}$, same as experimental result before. At the speed average 0 to 30 $\mathrm{km} / \mathrm{h}$, the SWAD was not detected due to the vehicle movement was too slow and programming set up. At speed between 40 to $70 \mathrm{~km} / \mathrm{h}$, the SWAD function well and showed the good result.

\section{Speed Range $(\mathrm{km} / \mathrm{h})$ vs Distance Detected At (m)}

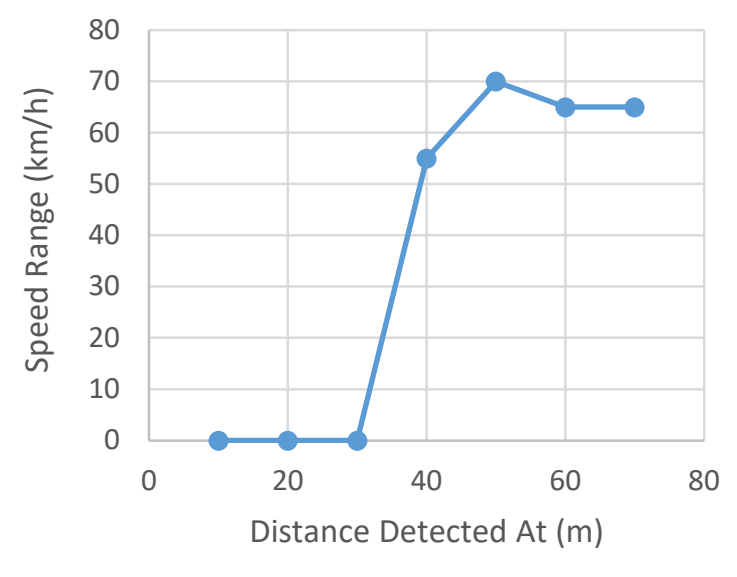

Fig. 6: The graph of speed range $(\mathrm{km} / \mathrm{h})$ versus distance detected at emergency lane.

While running this experimental research, there were several things that had been observed and a lot of things were determined related to radar distance sensor and Signal Warning Detector (SWAD) system. The challenges faced in this research were to get the reliable ${ }^{26)}$ and accurate $^{27)}$ data for radar distance sensor in detecting vehicle or other object to achieve the objective in decreasing the accident situation among maintenance highway workers. As regard with to SWAD system and its capability, it was very easy to manage and control as SWAD itself already developed to be compatible with highway emergency lane environment.

\section{Conclusion}

In conclusion, the objective of Signal Warning Detector (SWAD) study and experimental process which was to find the best result in emergency detection had been achieved. Several experiment had been run to find the maximum vehicle distance detection by radar distance sensor at different speed range in emergency lane. The experimental study was applied in finding the data for analysing due to new development of SWAD system that 
never been done before. While the value of distance sensor from the lane was obtained through several experiment on the site. The maximum distance detection was at 70 meter at speed $50 \mathrm{~km} / \mathrm{h}$. The highest speed which was $70 \mathrm{~km} / \mathrm{h}$ could detect the moving vehicle at 65 meter in emergency lane.

The data collected from several experiment showed the result of SWAD was achieved. Where the data obtained showed the system was run well where the transmitter detected the moving object and sent the signal to the receiver as early warning to highway maintenance workers to react and save their life. As the result of experimental testing, this SWAD system could be applied for the maintenance workers at the highway to increase their safety aspect and standard operation procedure (SOP). This system also could be used as safety features for all highway user in the future.

\section{Acknowledgements}

The authors acknowledge MTUN Grant (K239), Industrial Grant (M019), GPPS Grant (H584), GPPS Grant (H717), TIER 1 Grant (H197), Research Management Center and Faculty of Mechanical and Manufacturing Engineering (FKMP), Universiti Tun Hussein Onn Malaysia (UTHM), Ministry of High Education Malaysia for supporting the research activity. Special thanks to those who contributed to this research directly or indirectly.

\section{Nomenclature}

SWAD signal warning detector system

$I R \quad$ industrial revolution

$A C F \quad$ aggregated channel feature

IPM inverse perspective mapping

\section{References}

1) Eusofe Zarulazam and H. Evdorides, “Assessment of road safety management at institutional level in Malaysia: A case study,” Iatss Research 41, 172-181 (2017). doi.org/10.1016/j.iatssr.2017.03.002.

2) S. R. Masrol, M. H. I. Ibrahim, S. Adnan, M. S. S. Amir Shah, N. M. Main, M. F. Esa, and M. H. Othman, "Effect of Beating Process to Soda Anthraquinone Pulp of Oil Palm Male Flower Spikes Fibre,” Applied Mechanics and Materials, Vol. 773, 158-162 (2015). doi.org/10.4028/www.scientific.net/ amm.773-774.158.

3) F. Jalaei, and A. Jrade, "Integrating BIM with green building certification system, energy analysis, and cost estimating tools to conceptually design sustainable buildings," Construction Research Congress 2014: Construction in a Global Network. (2014). doi.org/10.1061/9780784413517.176.
4) S. Hassan, E.A. Rahim, Z. Mohid and N.M. Warap, "Dynamic Analysis of Micro-milling Machine," Applied Mechanics and Materials, vol. 465-466, pp. 699-703, (2013). doi.org/10.4028/www.scientific.net /AMM.465-466.699.

5) A. C. Ahmad, I. N. M. Zin, M. N. Rosli, A. M. A. Wahid, and I. F. M. Kamar, "Hazard and Risk of Highway Maintenance Works: Case Study of PLUS Expressways," In MATEC Web of Conferences, vol. 66, p. 00106. EDP Sciences, (2016). doi.org/10.1051/matecconf/20166600106.

6) S. Hassan, M. S. Yusof, Z. Embong, M. Z. I. Jumari, M. Ismon, H. Zakaria, M. Z. Rahim, R. Ahmad and E. M. N. E. Nasir, "A Preliminary Study of Additional Safety Mechanical Structure for Safety Shoe," In Advances in Material Sciences and Engineering, pp. 577-584. Springer, Singapore (2020). doi.org/ 10.1007/978-981-13-8297-0_59.

7) T. K. Koo, and M. Y. Li, "A guideline of selecting and reporting intraclass correlation coefficients for reliability research," Journal of chiropractic medicine 15, no. 2, 155-163. (2016). doi.org/10.1016/ j.jcm.2016.02.012.

8) E. A. Drost, "Validity and reliability in social science research," Education Research and perspectives 38, no. 1, 105 (2011). https://search.informit.com.au/ documentSummary;dn=491551710186460;res=IELI AC.

9) Q. Meng, Qiang, J. Weng, and X. Qu, "A probabilistic quantitative risk assessment model for the long-term work zone crashes," Accident Analysis \& Prevention 42, no. 6, 1866-1877 (2010). doi.org/ 10.1016/j.aap.2010.05.007.

10) V. Vignali, A. Bichicchi, A. Simone, C. Lantieri, G. Dondi, and M. Costa, "Road sign vision and driver behaviour in work zones," Transportation research part F: traffic psychology and behaviour 60, 474484 (2019). doi.org/10.1016/j.trf.2018.11.005.

11) S. Ramadhanty, M. H. Amirullah, M. H. Faturrahman, R. Dhelika, and Tomy Abuzairi, "Development of Small Scale Electrohydrodynamic Drying Device for Rough Rice Using DC Plasma Generator," Evergreen 6, no. 2, 103-107 (2019).

12) S. Hassan, M.S. Yusof, M.I. Maksud, M.N. Nodin, K.A. Mamat, M.S. Sazali, W.I.S. Zainun, M.Z. Rahim and M.H. Rahman, "A Study of PDMS Printing Plate for Fine Solid Lines Image in Micro-Flexographic Printing Process," Journal of Engineering and Applied Sciences, vol. 12, pp. 5644-5649, (2017). doi: 10.36478/jeasci.2017.5644.5649.

13) M. N. Roslan, M. Y. Yahya, Z. Ahmad, and A. H. A. Rashid, "Axial impact crushing behaviour of thinwalled braided composite tubes: experimental comparison on basalt fibre and glass fibre reinforcement," In Journal of Physics: Conference Series, vol. 1150, no. 1, p. 012048. IOP Publishing, (2019). doi.org/10.1088/1742-6596/1150/1/012048. 
14) K. Kamarudin, M. S. Wahab, M. F. M. Batcha, Z. Shayfull, A. A. Raus, and Aqeel Ahmed, "Cycle time improvement for plastic injection moulding process by sub groove modification in conformal cooling channel," In AIP Conference Proceedings, vol. 1885, no. 1, p. 020176. AIP Publishing LLC (2017). doi.org/10.1063/1.5002370.

15) M. F. Sies, N. Mustaffa, H. Zakaria, H. Salleh, B. Manshoor, and A. Khalid, "Development of the premixing injector in burner system," Vol. 465. Trans Tech Publications Ltd. (2014). doi.org/10.4028/ www.scientific.net/AMM.465-466.302.

16) N. Mustaffa, A. Khalid, M. F. Sies, H. Zakaria, and B. Manshoor, "Preheated biodiesel derived from vegetable oil on performance and emissions of diesel engines: A review," In Applied Mechanics and Materials, vol. 465, pp. 285-290. Trans Tech Publications Ltd. (2014). doi.org/10.4028/ www.scientific.net/AMM.465-466.285.

17) B. Ravani, and C. Wang, "Speeding in highway work zone: an evaluation of methods of speed control," Accident Analysis \& Prevention 113. 202212 (2018). doi.org/10.1016/j.aap.2018.01.030.

18) F. Wegman, "The future of road safety: A worldwide perspective," IATSS research 40, no. 2 (2017): 66-71 (2017). doi.org/10.1016/j.iatssr.2016.05.003.

19) M. M. Rahman, L. Strawderman, T. Garrison, D. Eakin, and C. C. Williams, "Work zone sign design for increased driver compliance and worker safety," Accident Analysis \& Prevention 106, 67-75 (2017). doi.org/10.1016/j.aap.2017.05.023.

20) J. A. Volpe, and V. E. Hommes, "Assessment of Safety Standards for Automotive Electronic Control Systems," Report No. DOT HS 812285. 1-49. (2016). https://ntl.bts.gov/lib/59000/59300/59359/812285_E lectronicsReliabilityReport.pdf.

21) J. B. Kim, "Efficient vehicle detection and distance estimation based on aggregated channel features and inverse perspective mapping from a single camera," Symmetry, $11 \quad$ (10), pp.1205 (2019). doi:10.3390/sym11101205.

22) M. Ismon, M. D. Jamalludin, I. Zaman., N. A. Azmir, R. Asmawi, M. F. Sies, M. N. Roslan, and Z. Ibrahim, "Pitting Hole Evaluation by Active Infrared Thermography in Stainless Steel 304," Journal Of Advanced Research In Fluid Mechanics And Thermal Sciences, Penerbit Akademia Baru, 3, 114-124 (2020). doi.org/10.37934/arfmts.68.1.114124.

23) S. Hassan, M. S. Yusof, Z. Embong, S. Ding, and O. M. F. Marwah, "A Study Of Printing Plate Mould Development By Using 3d Printers For MicroFlexographic Printing Process," Journal of Advanced Manufacturing Technology (JAMT) 14, no. 1 (2020). https://jamt.utem.edu.my/jamt/article/view/5856.
"Analysis of Characteristics and Efficiency of Smart Locker System (Case Study: Jabodetabek)," Evergreen 7, no. 1, 111-117 (2020).

25) S. Hassan, M. Z. I. Jumari, M. A. A. Sahari, M. A. M. Bahtiar, M. H. Jaafar, M. A. M. Nadir, M. S. M. Zakaria, M. S. Yusof, M. Ismon, H. Zakaria, M. A. Azmi, N. M. Yusof, and M. S. Ikhsan, "A study of sensor signal danger detector system using Arduino programming method," AIP Conference Proceedings, vol. 2339, no. 1, pp. 020041 (2021). https://doi.org/10.1063/5.0044356.

26) Ko, Jaedeok, Nobuo Takata, Kyaw Thu, and Takahiko Miyazaki. "Dynamic modeling and validation of a carbon dioxide heat pump system." PhD diss., Kyushu University, (2020).

27) Y. Whulanza, A. T. Hakim, S. M. Utomo, R. Irwansyah, and J. Charmet, "Design and Characterization of Finger-Controlled Micropump for Lab-on-a-Chip Devices," Evergreen 6, no. 2, 108113 (2019). 